\title{
Hepatocellular carcinoma presenting as spinal cord compression in Native Americans with controlled hepatitis C: two case reports
}

\author{
Maksim Liaukovich', Susan $\mathrm{Wu}^{2}$, Sydney Yoon ${ }^{3}$, Jeff Schaffer ${ }^{4}$ and Jen C. Wang ${ }^{1 *}$ (D)
}

\begin{abstract}
Background: Hepatocellular carcinoma is a common malignancy in Asia. It is associated with chronic hepatitis B virus or hepatitis $C$ virus infection and alcoholic hepatitis. Commonly, the tumor metastasizes to the lungs, regional lymph nodes, and bone. Recently, the incidence of metastatic spinal cord compression caused by primary hepatocellular carcinoma has been reported more frequently due to improved diagnosis and therapeutic modalities. The presentation of primary hepatocellular carcinoma with spinal cord compression is very rare. To the best of our knowledge, there are only 33 such cases published to date. The majority of cases involve patients of Asian origin and are associated with hepatitis B infection.
\end{abstract}

Case presentation: We report consecutive cases of two Native American (American Indian) patients (a 64-year-old man and a 70-year-old man) who presented with symptoms of spinal cord compression due to metastatic spread of hepatocellular carcinoma and were associated with hepatitis C infection. In one of these cases, the hepatitis C infection had been successfully controlled (hepatitis $C$ titers were undetectable for 1 year before he presented with spinal cord compression). This occurrence in a Native American with a controlled hepatitis $C$ infection has not been reported previously.

Conclusions: Primary care physicians, oncologists, and gastroenterologists should be cognizant of this unusual presentation of hepatocellular carcinoma in a Native American. Such knowledge may help improve early diagnosis and survival.

Keywords: Hepatocellular carcinoma, Hepatitis C, Native American

\section{Background}

Hepatocellular carcinoma (HCC) is a common malignancy in Southeast Asia. HCC and respiratory system cancers are the most common cause of cancer-related deaths in Taiwan $[1,2]$. HCC is the fourth highest cause of cancer-related death in Japan [3] and the fifth most common cancer diagnosed in Korea [4]. Due to better diagnosis, improvements in management, and prolonged survival of patients, an increasing number of patients are diagnosed after extrahepatic spread. The most common sites of metastases are the

\footnotetext{
* Correspondence: jcwang0005@Gmail.com

${ }^{1}$ Division of Hematology/Oncology, Brookdale University Hospital Medical Center, Brooklyn, NY 11212, USA

Full list of author information is available at the end of the article
}

lungs, lymph nodes, and bones [5]. While axial skeletal metastasis is common in HCC, initial presentation as spinal cord/root compression is extremely rare, and it may cause paralysis and bowel and bladder dysfunction. Early disease-focused treatment includes radiotherapy and surgery, which play a crucial role in decreasing spinal cord compression and improving quality of life. To the best of our knowledge, there are 33 cases published to date (Table 1). We did not find any reports of HCC presenting as spinal cord/root compression in Native Americans.

We report the cases of two Native American patients who presented with spinal cord compression secondary to HCC metastasis associated with hepatitis $\mathrm{C}$ infection.

(c) The Author(s). 2018 Open Access This article is distributed under the terms of the Creative Commons Attribution 4.0 International License (http://creativecommons.org/licenses/by/4.0/), which permits unrestricted use, distribution, and 
Table 1 Summary of cases of hepatoma presenting with spinal cord compression

\begin{tabular}{|c|c|c|c|c|c|c|c|c|}
\hline Case \# & $\begin{array}{l}\text { Year of } \\
\text { publication }\end{array}$ & Authors & $\begin{array}{l}\text { Age } \\
\text { (years) }\end{array}$ & Sex & Race & Underlying liver disease & $\begin{array}{l}\text { Activity of } \\
\text { disease }\end{array}$ & Presenting symptom \\
\hline 1 & 1989 & $\begin{array}{l}\text { Omura et } \\
\text { al. [24] }\end{array}$ & 57 & M & Paper from Japan & Not reported & Not reported & Paraplegia \\
\hline $2-17$ & 1992 & Lee [12] & $26-59$ & $\begin{array}{l}\mathrm{M} / \\
\mathrm{F}\end{array}$ & $\begin{array}{l}\text { n/a (paper from } \\
\text { Taiwan) }\end{array}$ & $75 \%(12 / 16)$ hepatitis B positive & Not reported & $\begin{array}{l}\text { - Pain/weakness in the distribution } \\
\text { of thoracic/lumbar spine - } 8 \text { cases } \\
\text { - Arm weakness - } 2 \text { cases } \\
\text { - Scalp mass - } 3 \text { cases } \\
\text { - Right hemicranias - } 1 \text { case } \\
\text { - Diplopia - } 1 \text { case } \\
\text { - Dysarthria - } 1 \text { case }\end{array}$ \\
\hline 18 & 1993 & $\begin{array}{l}\text { Kantharia et } \\
\text { al. [25] }\end{array}$ & 45 & M & $\begin{array}{l}\text { n/a (paper from, } \\
\text { Syracuse, NY state) }\end{array}$ & $\begin{array}{l}\text { Hepatitis C, hepatitis B, and } \\
\text { alcoholic liver disease with } \\
\text { cirrhosis }\end{array}$ & Not reported & Low back pain \\
\hline 19 & 1997 & $\begin{array}{l}\text { Yang et al. } \\
{[26]}\end{array}$ & 37 & M & $\begin{array}{l}\text { n/a (paper from } \\
\text { Hong Kong) }\end{array}$ & Hepatitis B & Not reported & Low back pain \\
\hline 20 & 1997 & $\begin{array}{l}\text { Yang et al. } \\
{[26]}\end{array}$ & 47 & $\mathrm{~F}$ & $\begin{array}{l}\text { n/a (paper from } \\
\text { Hong Kong) }\end{array}$ & Not reported & Not reported & Low back pain \\
\hline 21 & 1998 & $\begin{array}{l}\text { Razana et } \\
\text { al. [27] }\end{array}$ & 77 & M & Malay (Asian) & Alcoholic with liver cirrhosis & $\begin{array}{l}\text { ALT and AST } \\
\text { were elevated }\end{array}$ & $\begin{array}{l}\text { Right lower limb weakness and } \\
\text { paresthesia }\end{array}$ \\
\hline 22 & 1998 & $\begin{array}{l}\text { Razana et } \\
\text { al. [27] }\end{array}$ & 68 & M & Malay (Asian) & Not reported & Not reported & $\begin{array}{l}\text { Sudden onset of lower extremities } \\
\text { paraparesis }\end{array}$ \\
\hline 23 & 2003 & $\begin{array}{l}\text { Po et al. } \\
{[28]}\end{array}$ & 60 & M & $\begin{array}{l}\text { n/a (paper from } \\
\text { Taiwan) }\end{array}$ & Hepatitis B and C & Remission & Low back pain \\
\hline 24 & 2005 & $\begin{array}{l}\text { Garcia and } \\
\text { Castillo [29] }\end{array}$ & 49 & M & Not reported & $\begin{array}{l}\text { Alcohol abuse, } \\
\text { hepatitis B and } C \text { negative }\end{array}$ & Not reported & Low back pain \\
\hline 25 & 2006 & $\begin{array}{l}\text { Doval et al. } \\
\text { [30] }\end{array}$ & 55 & M & $\begin{array}{l}\text { Not reported } \\
\text { (paper from } \\
\text { China) }\end{array}$ & Hepatitis B & Remission & Low back pain \\
\hline 26 & 2006 & $\begin{array}{l}\text { Doval et al. } \\
{[30]}\end{array}$ & 70 & M & $\begin{array}{l}\text { Not reported } \\
\text { (paper from } \\
\text { China) }\end{array}$ & $\begin{array}{l}\text { Alcoholic, hepatitis B and C } \\
\text { negative }\end{array}$ & Not reported & Chest pain \\
\hline 27 & 2006 & $\begin{array}{l}\text { Doval et al. } \\
\text { [30] }\end{array}$ & 62 & M & $\begin{array}{l}\text { Not reported } \\
\text { (paper from } \\
\text { China) }\end{array}$ & $\begin{array}{l}\text { Nonalcoholic, hepatitis B and C } \\
\text { negative }\end{array}$ & Not reported & Pain in the neck and low back \\
\hline 28 & 2011 & $\begin{array}{l}\text { Vargas et al. } \\
{[31]}\end{array}$ & 50 & M & $\begin{array}{l}\text { Not reported } \\
\text { (paper from USA) }\end{array}$ & Alcohol abuse, hepatitis B & $\begin{array}{l}\text { AST } 146 \mathrm{U} / \mathrm{L} \text {, } \\
\text { ALT } 84 \mathrm{U} / \mathrm{l}\end{array}$ & Low back pain \\
\hline 29 & 2014 & $\begin{array}{l}\text { Nangolo et } \\
\text { al. [5] }\end{array}$ & 46 & M & Namibian (Africa) & $\begin{array}{l}\text { Alcoholic hepatitis and hepatitis } \\
\text { B }\end{array}$ & $\begin{array}{l}\text { AST } 180 \mathrm{IU} / \mathrm{I} \\
\text { and ALT } 70 \mathrm{IU} / \mathrm{I}\end{array}$ & b/l leg weakness \\
\hline 30 & 2014 & $\begin{array}{l}\text { Vallianou et } \\
\text { al. [32] }\end{array}$ & 79 & M & $\begin{array}{l}\text { n/a (paper from } \\
\text { Greece) }\end{array}$ & Hepatitis B (not on medications) & Not mentioned & $\begin{array}{l}\text { Upper extremity muscle pain and } \\
\text { paresthesia }\end{array}$ \\
\hline 31 & 2015 & $\begin{array}{l}\text { Hwang et } \\
\text { al. [4] }\end{array}$ & 61 & M & $\begin{array}{l}\text { n/a (paper from } \\
\text { South Korea) }\end{array}$ & Hepatitis B & $\begin{array}{l}\text { AST } 418 \mathrm{U} / \mathrm{l} \\
\text { ALT } 594 \mathrm{U} / \mathrm{l} \\
\text { HBV DNA } \\
1890769 \\
\text { copies/mL }\end{array}$ & $\begin{array}{l}\text { Upper extremity weakness and } \\
\text { tingling }\end{array}$ \\
\hline 32 & 2016 & $\begin{array}{l}\text { Sangli et al. } \\
{[14]}\end{array}$ & 49 & M & $\begin{array}{l}\text { Emigrant from } \\
\text { Ghana }\end{array}$ & Hepatitis B not on medications & $\begin{array}{l}\text { ALT and AST } \\
\text { WNL }\end{array}$ & $\begin{array}{l}\text { Left lower extremity weakness and } \\
\text { numbness }\end{array}$ \\
\hline 33 & 2017 & $\begin{array}{l}\text { Ayyadurai } \\
\text { et al. [13] }\end{array}$ & 58 & M & $\begin{array}{l}\text { n/a (paper from } \\
\text { Bronx, USA) }\end{array}$ & Hepatitis C and alcohol abuse & LFTs WNL & Neck pain \\
\hline 34 & 2017 & Our patient & 64 & M & Native American & $\begin{array}{l}\text { Hepatitis C (treated, no viral load } \\
\text { detected) }\end{array}$ & $\begin{array}{l}\text { ALT 505, AST } \\
210 \text {, bilirubin } \\
1.5\end{array}$ & Lower back pain and numbness \\
\hline 35 & 2017 & Our patient & 70 & M & Native American & $\begin{array}{l}\text { Hepatitis C Ab positive. RNA not } \\
\text { detected }\end{array}$ & $\begin{array}{l}\text { ALT 90, } \\
\text { AST } 104\end{array}$ & $\begin{array}{l}\text { Upper back pain and numbness of } \\
\text { right foot }\end{array}$ \\
\hline
\end{tabular}

$A b$ antibody, $A L T$ alanine aminotransferase, $A S T$ aspartate aminotransferase, $b / l$ bilateral, $F$ female, $H B V$ hepatitis $B$ virus, $L F T s$ liver function tests, $M$ male, $n / a$ not available, $W N L$ within normal limits

In one of these cases, the hepatitis $\mathrm{C}$ infection had been successfully controlled. Hepatitis $C$ titers were undetectable for a year before the patient developed spinal cord compression. We did not find any literature reporting $\mathrm{HCC}$ presenting with spinal cord compression in Native Americans. 


\section{Case presentation}

Case 1

A 64-year-old Native American man presented with worsening lower back pain, and numbness and tingling radiating from his belly button down both legs. At the time of admission, he reported gradually increasing weakness in both legs for 3 days that led to an inability to walk. His past medical history is significant for hepatitis C for many years, which led to liver cirrhosis. His past surgical history is significant for a previously repaired umbilical hernia. His family history included breast cancer (sister) and lung cancer (mother). He smoked cigarettes for 1-2 years in the 1980s, but it is unknown how many cigarettes he smoked per day. In addition, he was a former heroin abuser. He never consumed alcohol. He worked as a manager in the laundry department in a hospital. Family members deny any exposure to asbestos. An ultrasound of his liver 1 year prior to the current presentation reported coarse echotexture, suggestive of underlying cirrhosis. Several years earlier, he had not responded to interferon and ribavirin treatment. However, 1 year before presentation, he did respond to ledipasvir/sofosbubir (Harvoni) treatment. Although he cut the treatment short to just 5 weeks, a recent hepatitis viral test detected no hepatitis $\mathrm{C}$ ribonucleic acid (RNA). He had hepatitis $\mathrm{C}$ virus (HCV) RNA genotype 1a. He was a prior intravenous drug user and was in a methadone program. Home medications were as follows: nadolol, spironolactone, bumetanide, and methadone. On admission, his blood pressure (BP) was 109/67 mm Hg, heart rate (HR) 57 beats per minute, and temperature $36.6{ }^{\circ} \mathrm{C}$. A physical examination had the following results: no jugular venous distention, his lungs were clear to percussion and auscultation, his heart sounded normal, there were no murmurs, his abdomen was slightly distended, his spleen and liver were not palpable, and some spider angioma was noted on his skin. On neurological examination: he was alert and awake; he was oriented to time, his name, and his location; and his cranial nerves were grossly intact. While no gait disturbance was observed, marked weakness of his lower extremities and swelling over the T9 area of his spine were found. He had a blood urea nitrogen (BUN) of $66 \mathrm{mg} / \mathrm{dL}$, creatinine of $2.8 \mathrm{mg} / \mathrm{dL}$, alkaline phosphatase of $505 \mathrm{U} / \mathrm{L}$, aspartate aminotransferase of $210 \mathrm{U} / \mathrm{L}$, alanine aminotransferase of $66 \mathrm{U} / \mathrm{L}$, and total bilirubin of $1.5 \mathrm{mg} / \mathrm{dL}$. Magnetic resonance imaging (MRI) of his thoracic and lumbar spine revealed a pathologic fracture at T11 with retropulsion and severe cord compression (Fig. 1) and right chest wall and thoracic spine mass with tumor invasion into the spinal canal and thoracic cord compression at T6 (Fig. 2). In addition, numerous metastatic lesions in his thoracic and lumbar spine were noted. A MRI scan of his chest/abdomen and pelvis without contrast was performed and revealed

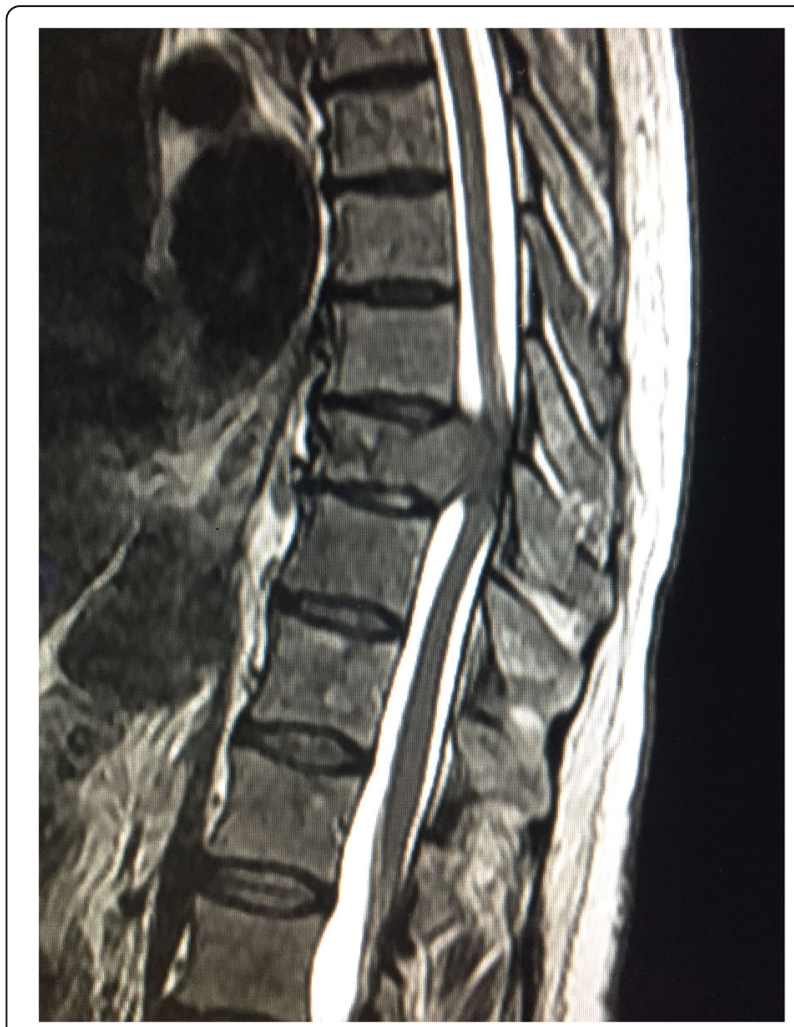

Fig. 1 Magnetic resonance imaging of the thoracic spine, sagittal short T1 inversion recovery sequence. Demonstrates T11 metastasis with pathologic fracture and retropulsion of the vertebral body into the spinal canal with thoracic cord compression

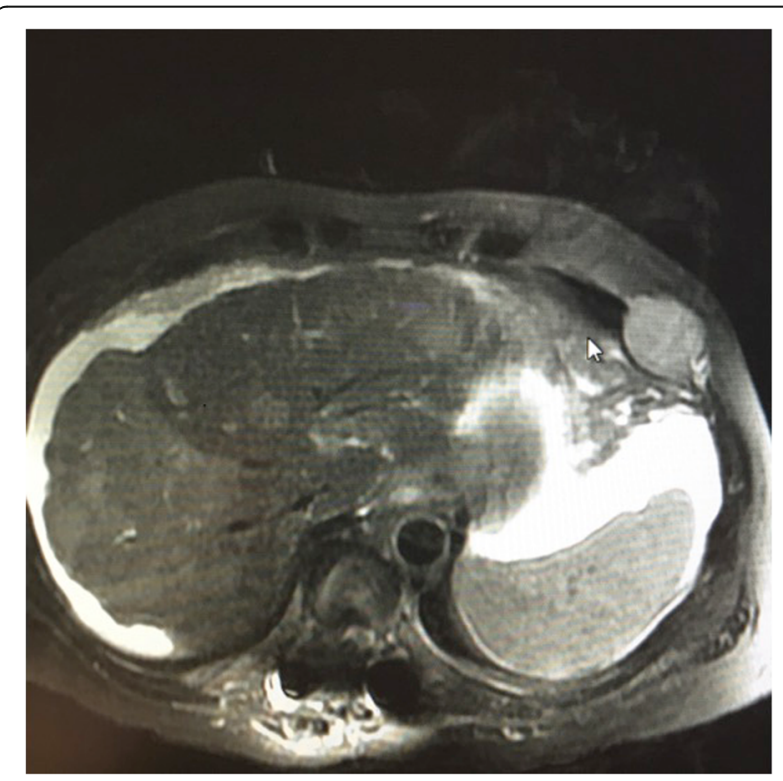

Fig. 2 Magnetic resonance imaging of the thoracic spine. Axial T2 sequence demonstrates right chest wall and thoracic spine mass with tumor invasion into the spinal canal and thoracic cord compression at T6 
a large right liver mass and multiple lesions in his ribs, spine, and mediastinum, suggestive of metastatic disease. He was started on intravenously administered steroids. Surgical spinal cord decompression and stabilization/fusion of his spine was performed. Pathology results of an intervertebral disc and the T9 vertebral body reported metastatic carcinoma favoring HCC (Fig. 3). Tumor cells were positive for Hep Par-1 and glypican-3 (Fig. 4), and negative for cytokeratin (CK) 7, CK20, thyroid transcription factor 1 (TTF-1), inhibin, OCT3/4, prostate-specific antigen (PSA), prostatic specific acid phosphatase (PSAP), renal carcinoma marker (RCC), and PAX8. Subsequently, he was treated with radiation to the T11 spine lesion and was scheduled to begin radioembolization with yttrium-90, but his condition deteriorated, and he died 2 months after diagnosis. An autopsy was not performed.

\section{Case 2}

The second case involved a 70-year-old Native American man presenting with upper back pain and numbness of his right foot for approximately 10 days. The symptoms had worsened, and he noticed some difficulty with walking. He did not have any past medical or surgical history. He was a former tobacco smoker and stopped smoking approximately 20 years ago, but it is unknown how many packs or cigarettes per day he smoked. He drank alcohol very rarely and not significantly. He did not have family history of any significance. He was never on medications until he was diagnosed as having HCC. He worked at a warehouse in the past. His job position was unknown. He has no known environmental or drug allergies. On admission, his BP was 166/119 mm Hg, HR was 97 beats per minute, and temperature was $36.7{ }^{\circ} \mathrm{C}$. His physical examination had the following results: he was normocephalic, he had a non-traumatic skull, he had normal hearing, he had no nasal discharge, his chest wall movement was symmetric, his breath sounds were clear, he had no rales/ wheezing, his HR was within the normal limit and had

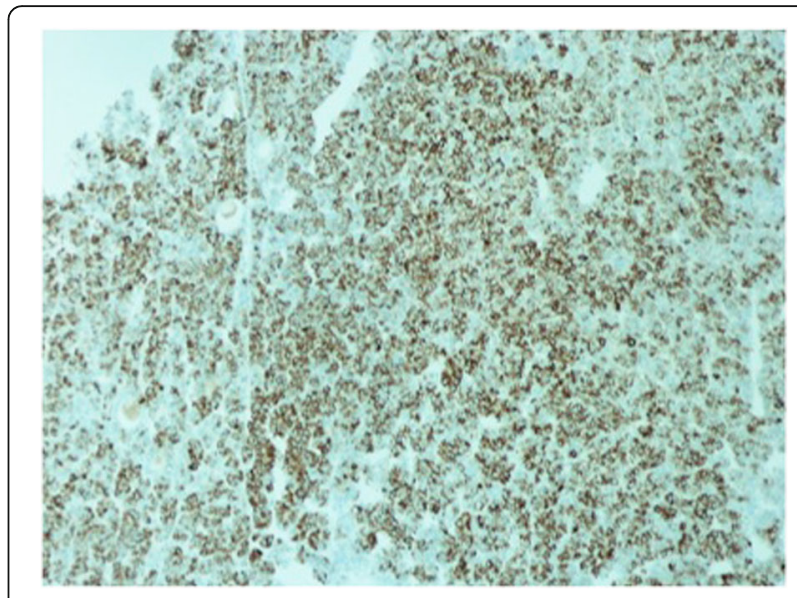

Fig. 4 Immunostaining of Hep Par-1 and glypican-3. 10x: Hep Par-1 and glypican-3 both show tumor cells to be diffuse strongly positive stains

regular rhythm with no murmurs or thrills, his abdomen was soft with no distension, there was no palpable mass, there was no hepatomegaly or splenomegaly, a bilateral pedal pulse was present, there was no visible joint swelling, his skin was warm to the touch, he had normal color, and he had no rash/ulcers. A neurological examination had the following results: he was alert and awake; he was oriented to time, his name, and his location; his cranial nerves were grossly intact; he had no gait disturbance or motor deficits; his superficial reflexes were intact; a slight decrease in sensation over his right lower extremity was noted. Abnormal laboratory results were as follows: aspartate aminotransferase level of $104 \mathrm{U} / \mathrm{L}$ and alanine aminotransferase level of $90 \mathrm{U} / \mathrm{L}$. CT of his chest and abdomen revealed a $10.0 \times$ $8.3 \times 7.4 \mathrm{~cm}$ soft tissue mass with associated osseous destruction involving the posterior right fourth, fifth, and sixth ribs and adjacent thoracic vertebral bodies, with significant soft tissue extension into the spinal canal and evidence of spinal cord compression. An additional lesion of the left iliac wing measuring $3.6 \mathrm{~cm}$ was noted. There were numerous enhancing lesions throughout his liver that were suspicious for primary versus metastatic disease
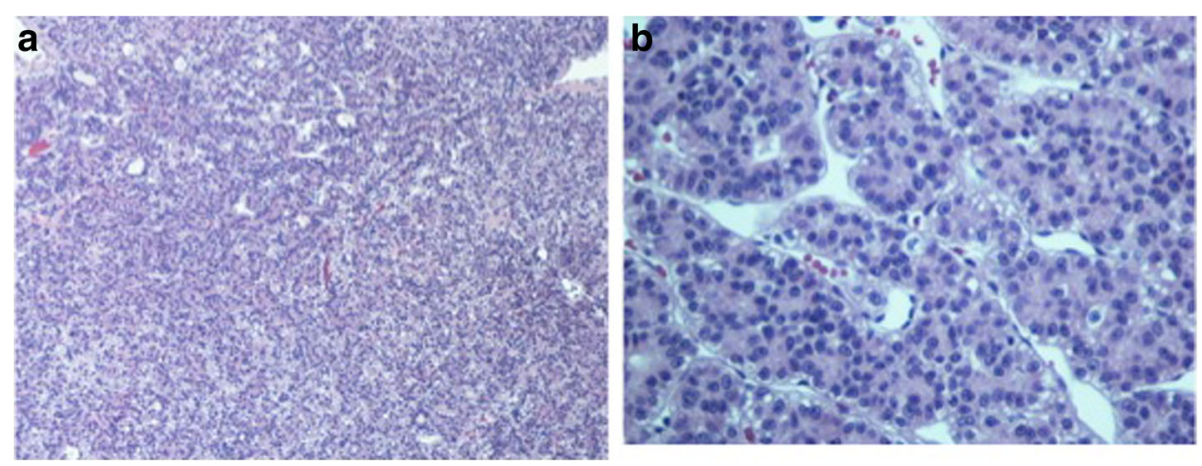

Fig. 3 a Hematoxylin and eosin 10x; b high power view, section of the specimen shows solid or packed papillary pattern with fibrovascular cords 


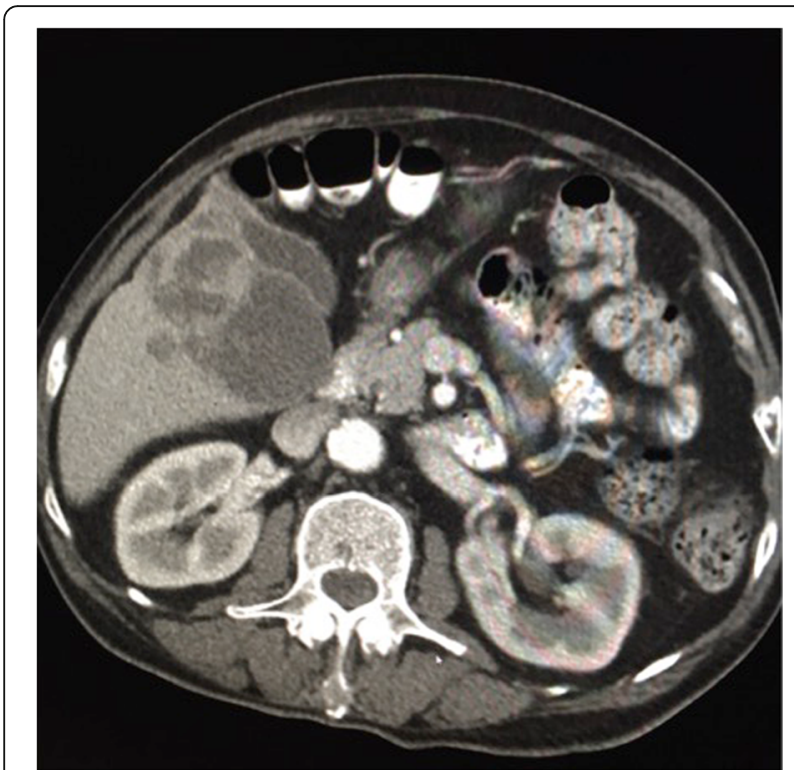

Fig. 5 Computed tomography of the abdomen and pelvis with contrast demonstrates a right hepatic mass with a cystic component. The gallbladder is medial to the mass

(Fig. 5). No signs of cirrhosis were detected on CT images. Further laboratory tests showed alpha-fetoprotein (AFP) levels of 98,884.0 ng/mL. Carcinoembryonic antigen (CEA) and cancer antigen (CA) 19-9 levels were slightly elevated. Hepatitis C RNA genotype 1a was detected. Hepatitis C RNA was $6.73 \log \mathrm{IU} / \mathrm{mL}$ by reverse transcriptase polymerase chain reaction (RT-PCR).

An MRI of his thoracic spine was performed and revealed a large, posterior, left chest wall mass measuring $10.0 \times 6.7 \times 9.5 \mathrm{~cm}$, with associated osseous destruction of the underlying right posterior fourth through seventh ribs and adjacent vertebral bodies, with complete obstruction of the right foramen and significant involvement of his spinal canal, causing spinal cord compression (Fig. 6). A biopsy of the soft tissue mass was performed and showed a metastatic, poorly differentiated carcinoma favoring hepatocellular origin (Fig. 7). Tumor cells were positive for hepatocyte, glypican-3, and pan-CK (Fig. 8), and focally positive for CK20 and CEA but were negative for CK7 and TTF-1, CA 19-9, p63, CDX2, and OCT3/4. Because of the poorly differentiated histology and atypical presentation, he was treated with oxaliplatin plus fluorouracil/leucovorin [6]. After radiation of T5-T7 and a subsequent decrease in AFP levels, he eventually refused further therapy and was placed on hospice care. He died 6 months after diagnosis. An autopsy was not performed.

\section{Discussion}

Metastasis to the spinal cord is a very unusual and rare presentation of HCC. To the best of our knowledge, only 33 such cases have been published to date (Table 1). Of

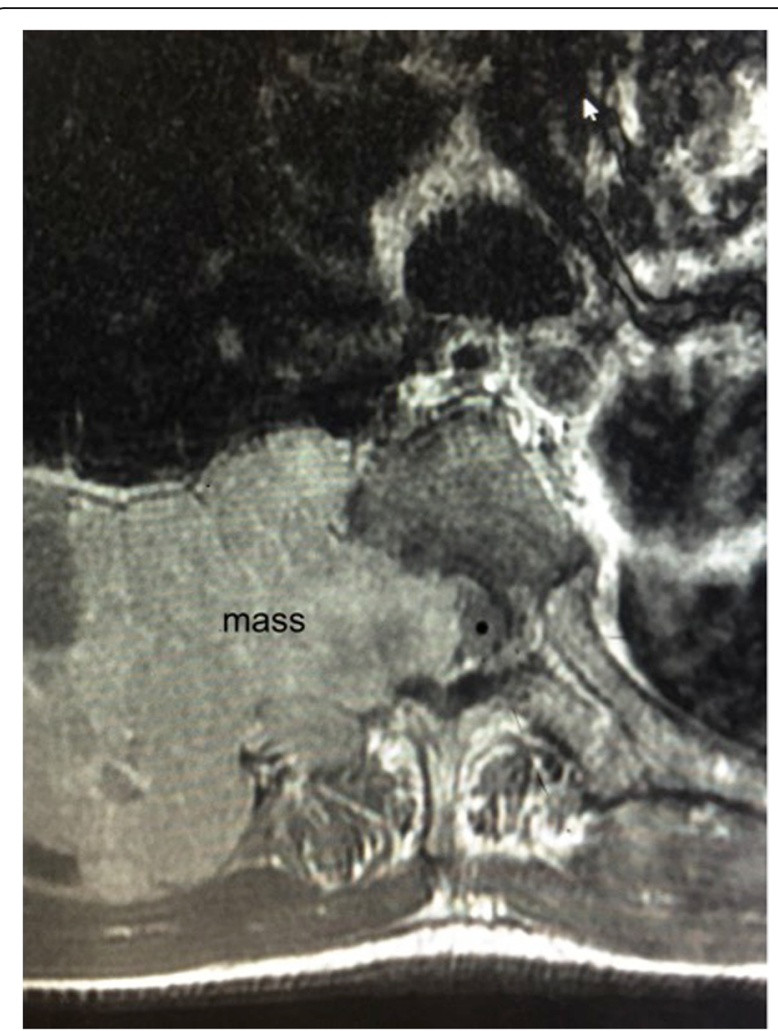

Fig. 6 Magnetic resonance imaging of the thoracic spine, sagittal short T1 inversion recovery sequence. Demonstrates metastases to the mid-thoracic spine, T5, T6, and T7, with tumor invasion into the spinal canal and cord compression from T5 to T7

those 33 patients, 21 had evidence of previous hepatitis $B$ infection, and two of them had hepatitis $C$ as well. One patient was positive for hepatitis $\mathrm{C}$ and had a history of alcohol abuse. Three patients had a history of alcohol abuse without evidence of viral hepatitis infection. One patient who was not an alcoholic was negative for both hepatitis B and C. Data on hepatitis serologies were not available for seven of the cases. The incidence of bone metastasis varies from $1 \%$ to $20 \%$ [7]. Due to improved diagnosis and therapeutic modalities for HCC, more cases of extrahepatic metastases, especially bone metastases, have been detected in recent years. We report two cases of Native Americans with HCC presenting with a spinal cord compression. We could not find any previous publications of HCC presenting with spinal cord compression in Native Americans. One of our cases had undetectable hepatitis $C$ RNA levels at the time of HCC diagnosis. In another case, there were no signs of liver cirrhosis when the patient was diagnosed as having HCC.

$\mathrm{HCC}$ is the most common primary hepatic cancer and is an uncommon cancer in Western countries, including the USA. The overall incidence in the USA is 0.21$0.57 \%$, but the incidence is higher in Asia and sub-Saharan Africa. In Japan, the relative frequency of 

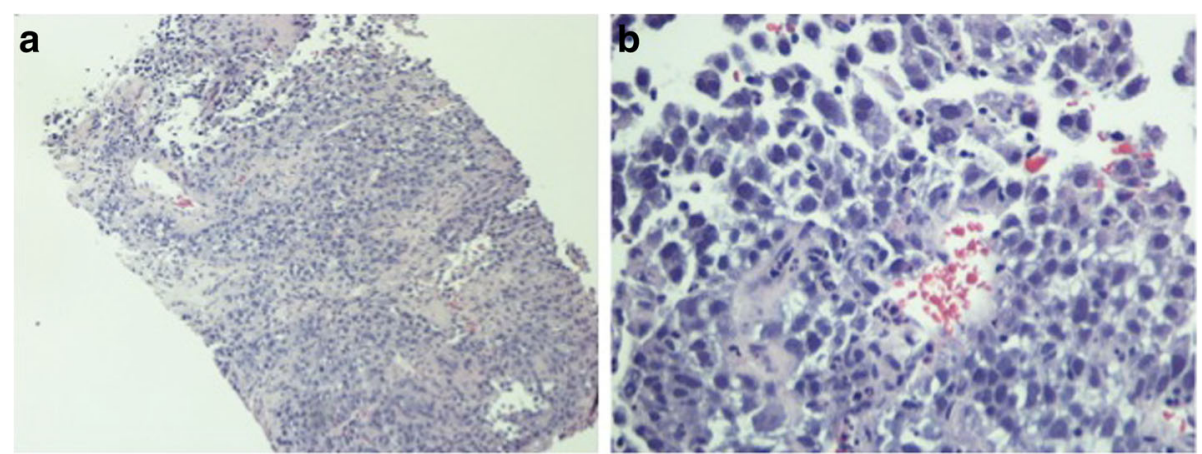

Fig. 7 a Hematoxylin and eosin 10x. Section of the specimen demonstrates infiltrative tumor cells in fibrous tissue; b high power view. Tumor cells with marked cytological pleomorphisms. There is abundant pink or clear cytoplasm. Nuclei are round to oval with irregular nuclear contour and hyperchromatic chromatin. Mitoses are frequently identified. Based on morphologic features, diagnosis of poorly differentiated carcinoma is suspected

HCC during autopsies is $2.57-4.8 \%$ [7]. It ranks as the fourth highest cause of cancer-related death in Japan [3]. The high incidence of $\mathrm{HCC}$ is largely driven by the high burden of hepatitis $\mathrm{B}$ and $\mathrm{HCV}$ infection in these regions $[3,5]$, with hepatitis B infection being found in $75-80 \%$ of patients with $\mathrm{HCC}[8,9]$. In the Asian population, the rate of seropositivity for hepatitis B surface antigen (HBsAg) approaches $100 \%$ in children with HCC compared with 70-80\% in adults with HCC [9].

An epidemiological study of HCC in Taiwanese children aged 6 to 14 began after the launch of a nationwide vaccination program in 1984. The average incidence of HCC declined from 0.70 per 100,000 children for the period of 1981 to 1986 to 0.36 per 100,000 children for the period of 1990 to 1994 [9]. In many developed nations, including the USA, HCV infection accounts for more than half of HCC cases, in contrast to Asian countries [10].

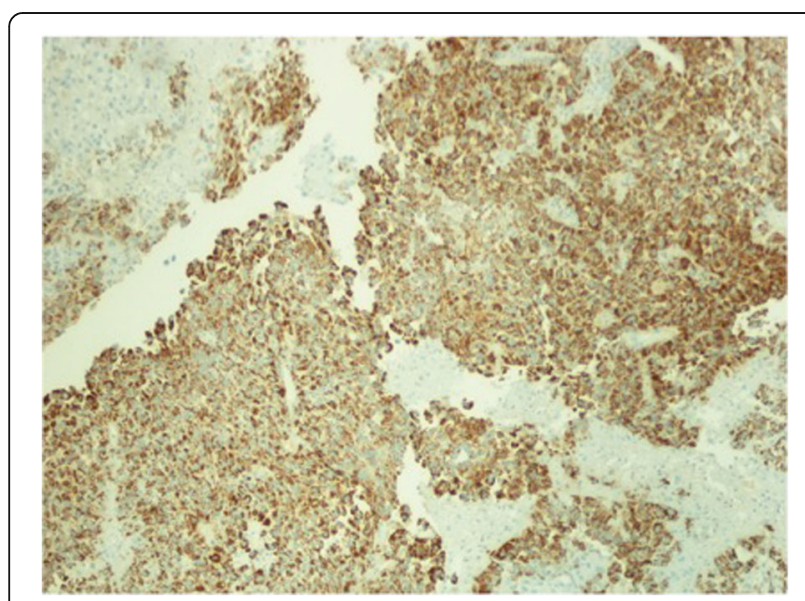

Fig. 8 Case 2. Immunostaining of Hep Par-1 and glypican-3. 10x: Hep Par-1 and glypican-3 both show tumor cells to be strongly positive diffuse stains
While the pathophysiology of $\mathrm{HCC}$ in hepatitis $\mathrm{C}$ or B infection is unclear, the chronic inflammatory process in the liver may play a significant role. The liver inflammatory processes stimulate growth, repair, and restoration of normal liver architecture. When liver inflammation becomes chronic, the balance of damage versus regeneration is impaired and stimulates the formation of excess fibrotic tissue. In the long term, liver inflammation leads to cirrhosis, which is characterized by abnormal liver architecture and function. Cirrhosis leads to end-stage liver disease, hepatic failure, and liver cancer [10]. HCC can also occur in non-cirrhotic patients, particularly in patients with hepatitis B infection [11].

The risk factors for HCC include Asian and African race, cirrhosis of the liver, and hepatitis $\mathrm{B}$ or $\mathrm{C}$ infection. $\mathrm{HCC}$ is one of the more aggressive neoplasms, with metastatic potential mainly targeting the lungs, lymph nodes, bone, and adrenal glands. Most patients with HCC present with hepatomegaly, right upper quadrant pain, and/or abdominal mass [12]. While bone metastasis is reported to occur in cases of $\mathrm{HCC}$, its presentation as spinal cord compression is extremely unusual [5, 12-14].

In Taiwan, $\mathrm{HCC}$ is the fifth most frequently diagnosed cancer and second highest cause of cancer-related mortality [15]. In the USA and other Western countries, HCC accounts for less than $2 \%$ of all neoplasms and is often related to hepatitis $C$ infection or alcohol intake. In Asia, where hepatitis B virus is endemic, HCC is commonly associated with hepatitis B infection [16]. In the USA, chronic HCV is the leading risk factor for HCC [17].

According to the population-based Surveillance Epidemiology and End Results registry data, the overall HCC incidence rate is approximately 6 per 100,000 in the USA. It is more common in Asian men [18]. However, the largest increase is occurring among Hispanics, followed by African Americans and non-Hispanic whites, with the lowest increase occurring among Asians [17, 18]. The 
incidence and mortality of HCC is highest in Southern USA (that is, Texas, Louisiana, and Mississippi) [18]. HCV infection is associated with a 15 -fold to 20 -fold increased risk of $\mathrm{HCC}$ compared with individuals who are $\mathrm{HCV}$ negative. Following establishment of HCV-related cirrhosis, HCC develops at an average annual rate of $1-8 \%$ [18]. The presence of any level of $\mathrm{HCV}$ viremia is a strong risk factor for HCC compared to the absence of viremia [18]. While a dose-response relationship between hepatitis C RNA level and liver cirrhosis has been reported [19], viral load is not associated with HCC [17]. Patients who are HCV positive with advanced fibrosis who clear viremia with antiviral treatment have a reduced, though not eliminated, risk of HCC [17]. HCC can occur even after more than 10 years have passed since successful HCV clearance [20]. It is suggested that $\mathrm{HCV}$ leads to irreversible changes in cellular signaling via mechanisms such as epigenetic activation or imprinting, which continue to drive carcinogenesis even after viral clearance [20]. Currently, the widespread implementation of novel direct-acting antivirals, which target the viral protease, polymerase, or nonstructural proteins, achieves $90 \%$ of the sustained virologic response. However, additional large studies with long-term follow-up are required to determine the $\mathrm{HCC}$ incidence rate after $\mathrm{HCV}$ eradication. Our first case demonstrates that even with eradication of hepatitis $\mathrm{C}$ infection, hepatoma still developed after many months.

The incidence of HCC in Native Americans was 3.5-6.6 per 100,000 [20], which is slightly higher than that in whites $(2.6-3.5$ per 100,000$)$ and slightly lower than that in African Americans (4.2-7.0 per 100,000) and Hispanics (4.8-8.0 per 100,000) [21]. Stewart et al. showed that cause-specific survival in Native Americans was slightly higher (44.6 weeks, 95\% confidence interval) than it was in whites (42.4 weeks, 95\% confidence interval) and African Americans (36.3 weeks, 95\% confidence interval) [22]. Xu et al. reported that in the USA, Asian patients demonstrated the highest overall survival of 15 months compared with white, black, and Native American patients who had an overall survival of 11 months, 9 months, and 12 months, respectively (all $p<0.05$ ) [23].

\section{Conclusions}

Most of the reported cases of HCC presenting with spinal cord compression have been reported in Asian countries, and most were associated with hepatitis B infection (Table 1). Our cases represent two patients of Native American origin, which, to the best of our knowledge, have never before been published. Both patients were hepatitis $C$ positive and negative for hepatitis B infection. Physicians should be aware of the differentials of spinal cord lesions, including $\mathrm{HCC}$, especially in patients suffering from hepatitis C, hepatitis B, or alcoholic liver disease. Patient survival could improve if $\mathrm{HCC}$ is diagnosed earlier.

\section{Funding}

Supported by Brookdale Research Fund.

Availability of data and materials

Data and supporting material were used from the patients' paper charts. Please contact authors for any additional information.

\section{Authors' contributions}

ML wrote the manuscript and reviewed the literature, SW reviewed the pathology and wrote the pathology interpretation, SY acquired the radiology images and made the interpretations, and SJ took care of patients and edited the manuscript. JCW took care of the patients and formulated ideas and suggestions to write the manuscript. All authors read and approved the final manuscript.

\section{Ethics approval and consent to participate}

The case report study was approved by Brookdale University and Hospital Center Research and Clinical Projects Committee (RCPC/IRB).

\section{Consent for publication}

Written informed consent was obtained from the patients' next of kin for publication of this case report and any accompanying images. A copy of the written consent is available for review by the Editor-in-Chief of this journal.

\section{Competing interests}

The authors declare that they have no competing interests.

\section{Publisher's Note}

Springer Nature remains neutral with regard to jurisdictional claims in published maps and institutional affiliations.

\section{Author details}

'Division of Hematology/Oncology, Brookdale University Hospital Medical Center, Brooklyn, NY 11212, USA. ²Department of Pathology, South Naussau Communities Hospital, Oceanside, NY, USA. ${ }^{3}$ Department of Radiology, South Naussau Communities Hospital, Oceanside, NY, USA. ${ }^{4}$ Department of Cardiology, South Naussau Communities Hospital, Oceanside, NY, USA.

Received: 7 February 2018 Accepted: 17 August 2018

Published online: 30 September 2018

\section{References}

1. Shyu HJ, Lung CC, Ho CC, Sun YHI, Co PC, Huang JY, Pan CC, Chiang YC, Chen SC, Liaw YP. Geographic patterns of hepatocellular carcinoma mortality with exposure to iron in groundwater in Taiwanese population: an ecological study. BMC Public Health. 2013;13:352.

2. Hsiao AJ, Chen LH, Lu TH. Ten leading causes of death in Taiwan: a comparison of two grouping lists. J Formos Med Assoc. 2015;114:679-80.

3. Nakamura N, Igaki H, Yamashita H, Shiraishi K, Tago M, Sasano N, Shiina S, Omata M, Makuuchi M, Ohtomo K, Nakagawa K. A retrospective study of Radiotherapy for spinal bone metastases from hepatocellular carcinoma (HCC). Jpn J Clin Oncol. 2007;37(1):38-43.

4. Hwang S, Lee J, Lee JM, Hong SH, Lee MA, Chun HG, Chu HJ, Lee SH, Jung ES. Hepatocellular carcinoma with cervical spine and pelvic bone metastases presenting as unknown primary neoplasm. Korean J Gastroenterol. 2015;66(1):50-4.

5. Nangolo HT, Roberto L, Segamwenge IL, Voigt A, Kidaaga F. Spinal cord compression: an unusual presentation of hepatocellular carcinoma. Pan Afr Med J. 2014;19:363. https://doi.org/10.11604/pamj.2014.19.363.4323.

6. Qin S, Bai Y, Lim HY, Thongparasert S, Chao Y, Fan J, Yang TS, Bhudhisawasdi V, Kang WK, Zhou Y, Lee JH, Sun Y. Randomized, multicenter, open-label study of oxaliplatin plus fluorouracil/leucovorin versus doxorubicin as palliative chemotherapy in patients with advanced hepatocellular carcinoma from Asia. J Clin Oncol. 2013;31(28):3501-8.

7. Lee YT, Geer DA. Primary liver cancer: pattern of metastasis. J Surg Oncol. 1987;36(1):26-31. 
8. Yeun MF, Hou JL, Chutaputti A. Hepatocellular carcinoma in the Asia pacific region. J Gastroenterol Hepatol. 2009;24(3):346-53.

9. Chang MH, Chen CJ, Lai MS, Hsu HM, Wu TC, Kong MS, Liang DC, Shau WI, Chen DS. Universal hepatitis B vaccination in Taiwan and the incidence of hepatocellular carcinoma in children. NIJM. 1997;336:1855-9.

10. Liang TJ, Heller T. Pathogenesis of hepatitis C-associated hepatocellular carcinoma. Gastroenterology. 2004;127(5 Suppl 1):S62-71.

11. Birke B. Hepatitis B and C viruses and hepatocellular carcinoma. Viruses. 2010;2:1504-9.

12. Lee J-P. Hepatoma presenting as a craniospinal metastasis: analysis of sixteen cases. J Neurol Neurosurg Psychiatry. 1992;55:1037-9.

13. Ayyadurai P, Badipatla KR, Chime C, Arjun S, Reddy P, Niazi M, Nayudu SK. Cervical spinal cord compression: a rare presentation of hepatocellular carcinoma. Case Reports Hepatol. 2017:8567695. https://doi.org/10.1155/ 2017/8567695

14. Sangli S, Mankal PK, Fowle E, Abed J, O'Reilly E, Kotler DP. An atypical initial presentation of hepatocellular carcinoma as spinal cord compression. J Gastrointest Dig Syst. 2016;6(2):1000416.

15. Davila JA, Morgan RO, Shaib Y, McGlynn KA, El-Serag HB. Hepatitis C infection and the increasing incidence of hepatocellular carcinoma: a population-based study. Gastroenterology. 2004;127(5):1372-80.

16. Park KW, Park JW, Choi JI, Kim TH, Kim SH, Park HS, Lee WJ, Park SJ, Hong EK, Kim CM. Survival analysis of 904 patients with hepatocellular carcinoma in a hepatitis B virus-endemic area. J Gastroenterol Hepatol. 2008;23(3):467-73.

17. Mittal S, El-Serag HB. Epidemiology of HCC: consider the population. J Clin Gastroenterol. 2013;40(0):S2-6.

18. El-Serag HB, Kanwal F. Epidemiology of hepatocellular carcinoma in the United States: Where are we? Where do we go? Hepatology. 2014;60(5): 1767-75.

19. Kirk GD, Mehta SH, Astemborski J, Galai N, Washington J, Higgins Y, Balagopal A, Thomas DL. HIV, age and severity of hepatitis C virusrelated liver disease: a cohort study. Ann Intern Med. 2013;158(9): 658-66.

20. Baumert TF, Juhling F, Ono A, Hoshida Y. Hepatitis C-related hepatocellular carcinoma in the era or new generation antivirals. BMC Med. 2017;15:52.

21. Altekruse SF, McGlynn KA, Reichman ME. Hepatocellular carcinoma, incidence, mortality and survival trends in the United States from 1975 to 2005. J Clin Oncol. 2009;27(9):1485-91.

22. Stewart SL, Kwong SL, Bowlus CL, Nguyen TT, Maxwell AE, Bastani R, Cack EW, Chen MS Jr. Racial/ethnic disparities in hepatocellular carcinoma treatment and survival in California, 1988-2012. World J Gastroenterol. 2016; 22(38):8584-95.

23. Xu L, Kim Y, Spolverato G, Pawlik TM. Racial disparities in treatment and survival of patient with hepatocellular carcinoma in the United States. Hepatobiliary Surg Nutr. 2016;5(1):43-52

24. Omura K, Kawaura Y, Murakami N, Moruta K, Iwa T, Sasaki S. A hepatocellular carcinoma revealed by paraplegia caused by a vertebra metastasis. Gan No Rinsho. 1989;35(12):1448-52.

25. Kantharia B, Nizam R, Friedman H, Vardan S. Case report: spinal cord compression due to metastatic hepatocellular carcinoma. Am J Med Sci. 1993;306:233-5.

26. Yang WT, Yeo W, Leung SF, Chan YL, Johnson PJ, Metreweli C. MRI and CT of metastatic hepatocellular carcinoma causing spinal cord compression. Clin Radiol. 1997;52:755-60

27. Razana A, Zairul-Nizam ZF, Hyzan MY, Razak MA. Spinal cord compression from metastatic hepatocellular carcinoma: a report of two cases. J Orthop Surg. 1998;6(2):79-84. https://www.scopus.com/record/display.uri?eid=2-s2 0-0032287059\&origin=inward\&txGid=9a4349ac252ccbd980a226c7a61 bda1 1 .

28. $\mathrm{Po} \mathrm{HL}$, Chen $\mathrm{PH}$, Cheng $\mathrm{SJ}$, Hseuh $\mathrm{H}$. Hepatocellular carcinoma with acute spinal cord compression as the initial presentation. Acta Neurol Taiwanica. 2003;12(4):191-5.

29. Garcia VA, Castillo R. Asymptomatic advanced hepatocellular carcinoma presenting with spinal cord compression. Dig Dis Sci. 2005;50(2):308-11.

30. Doval DC, Bhatia AK, Vaid AK, Pavithran K, Sharma JB, Hazarika D, Jena A Spinal cord compression secondary to bone metastases from hepatocellular carcinoma. World J Gastroenterol. 2006:12(32):5247-52
31. Vargas J, Gowans M, Valdergrift WA, Hope J, Giglio P. Metastatic hepatocellular carcinoma with associated spinal cord compression. Am J Med Sci. 2011;341(2):148-52

32. Vallianou NG, Gounari P, Skourtis A, Vourlakou C. Cervical mass as a presenting manifestation of hepatocellular carcinoma. Hippokratia. 2014; 18(3):285-7.
Ready to submit your research? Choose BMC and benefit from:

- fast, convenient online submission

- thorough peer review by experienced researchers in your field

- rapid publication on acceptance

- support for research data, including large and complex data types

- gold Open Access which fosters wider collaboration and increased citations

- maximum visibility for your research: over $100 \mathrm{M}$ website views per year

At BMC, research is always in progress.

Learn more biomedcentral.com/submissions 